\title{
GenotypexEnvironment Interactions and Stability for Grain Yield and its Components in WBPH Tolerant Rice (Oryza sativa L.) Genotypes
}

\author{
K. N. Prajapati ${ }^{1 *}$ and K. B. Kathiria ${ }^{2}$
}

${ }^{1}$ Assistant Professor, Polytechnic in agriculture, S. D. Agricultural University, Khedbrahma (385 506), India

${ }^{2}$ Director of Research and Dean P. G. Studies, Anand Agricultural University, Anand (388 110), India

\section{Corresponding Author}

K. N. Prajapati

e-mail: ketan.agrian@gmail.com

\author{
Article History \\ Article ID: 3 C0293 \\ Received in $03^{\text {rd }}$ October, 2017 \\ Received in revised form $29^{\text {th }}$ December, 2017 \\ Accepted in final form $25^{\text {th }}$ January, 2018
}

\begin{abstract}
The present study was conducted during kharif, 2013-2015 with three different seasons at Main Rice Research Station, Anand Agricultural University, Nawagam, Gujarat. The stability analysis was carried out to study genotype x environment interaction for grain yield per plant. Analysis of stability parameters revealed that the mean squares due to genotypes were significant for all the characters. However, variances for environments were significant for all the characters studied except plant height and hulling per cent revealed that environment differ from season to season. The mean sums of squares for genotypexenvironment interactions in pooled analysis were found significant only for grain yield per plant. This suggested that the genotypes under study had reacted differently to the environments for grain yield per plant and remaining characters showed non-significant mean squares indicated that environment had little effects on the expression of those characters. Based on stability parameter for grain yield per plant, genotypes viz., IR 71700-247-1-1-2, IR 13146-45-2-3, IR 04A 395, IR 09A 102, IR 09N 190, IR 10A 110, IR 78581-12-3-2-2, GAR 13 and Gurjari were identified as stable genotypes with average stability and wider general adaptability over the environments. While, IR 02A 585, IR 77334-99-2-3-2 and IR 09A 104 were identified stable for favorable environments.
\end{abstract}

Keywords: Genotypexenvironment interaction, stability analysis and rice

\section{Introduction}

Rice (Oryza sativa L.) is considered as one of the most important crop plants from Poaceae. Globally rice is planted in about 150 million ha and 497 million tonnes of produce is harvested annually (Anon., 2015). Out of this, Asia accounts for $90 \%$ of the production and consumption of rice. India has the world's largest area under rice with $36.84 \mathrm{mha}$ and is the second largest producer (124.05 $\mathrm{mt}$ in 2015-16) next only to China. The world population will increase to over 4.6 billion by 2050 , which demands more than $50 \%$ of rice needs to be produced what is produced at present to cope with the growing population (Sreedhar et al. 2011).

India is largest rice growing country in the world; however its productivity per unit area is low. Therefore, efforts to enhance rice productivity coupled with stability of performance under varying environments must receive top priority. As stability testing of promising early genotypes of prime importance for increasing and stabilizing yield in crop plants, present investigation was undertaken to isolate stable genotypes in rice. GXE interaction underlies the very success of a scientific crop improvement programme related to stability of genotype/varieties. Not only this, G×E also influences the post- breeding adaptive evaluation of improved strains before being released for commercial cultivation. In any crop, genotypes differ for their yielding ability when grown in different agroecological niches. An ideal genotype is one that yields high and stable in its performance across environments. Its stability can be judged on phenotypic basis, where phenotype may be defined as a linear function of genotype, environment and their interaction effects. Relative importance of main and interaction effects may vary from genotype to genotype and with environment. Thus, the study of GXE interaction serves as a guide and helps in identifying suitable genotype for various environmental niches and evaluation of high yield and desirable grain quality for different environments is one of the exciting research leads to successful evaluation of stable genotype against WBPB, which could be used for general cultivation. Therefore, the present investigation was carried out, identifying stable genotypes with high yield (Ajmera et al., 2017)

\section{Materials and Methods}

Fifty one WBPH resistance genotypes received from IRRI, Philippines along with checks (GAR 13, Gurjari and GR 11) 
were evaluated in Randomized Block Design with three replications in three different seasons viz., E1: Kharif (2013), E2: Kharif (2014) and E3: Kharif (2015) at Main Rice Research Station, Anand Agricultural University, Nawagam (Gujarat). Each plot consisted of twenty plants in a row keeping 20 and $15 \mathrm{~cm}$ inter and intra row spacing, respectively. The recommended package of practices was adopted to raise a good crop. Five competitive plants were randomly selected and tagged excluding border plants to minimize border effect. The observations on tagged plants were recorded on twelve characters i.e., day to $50 \%$ flowering, plant height $(\mathrm{cm})$, panicle length $(\mathrm{cm})$, effective tillers plant ${ }^{-1}$, test weight $(\mathrm{g})$, grain yield per plant $(\mathrm{g})$, grain length $(\mathrm{mm})$, grain breadth $(\mathrm{mm})$, grain length : breadth ratio, hulling (\%), milling (\%), head rice recovery (\%). The character day to $50 \%$ flowering was recorded on per plot basis. The data obtained were analysed for stability parameters as per method proposed by Eberhart and Russell (1966).

\section{Results and Discussion}

The data obtained from three seasons were subjected to statistical analysis as per Eberhart and Russell model (1966). The analysis of variance for stability with regard to grain yield and other related traits in rice are presented in Table 1. The mean squares due to genotypes were significant for all the characters; while, the mean square for environments were found to be significant for all the traits except plant height and hulling per cent when tested against pooled error. The genotype $x$ environment interaction was highly significant only for grain yield per plant. This indicated that the genotypes interacted significantly to different environments for grain yield per plant only. Further the environments+(genotypesxenvironments) mean squares revealed higher magnitude of environments (linear) and genotypes $x$ environments (linear) components indicating that the predictable component accounted major part of total variation. The environments + (genotypesxenvironments) interaction was observed to be significant for the characters days to 50 per cent flowering, panicle length, test weight and grain yield per plant. The further partitioning of environments + (genotypesxenvironments) component of variation revealed that the environments (linear) component of variation were observed to be significant for all the characters except plant height and hulling percentage. Further, the higher magnitude of mean squares for environment (linear) compared to genotypes $x$ environments (linear) indicated that linear response of environment account for the major part of total variation for all the characters studied. However mean square for pooled deviation was significant only for grain yield per plant. The results are akin with the findings of Bhelkar et al. (2004) and Bhakta and Das (2008).

Several workers also reported significant genotype $\mathrm{x}$

Table 1: Analysis of variance for phenotypic stability for different characters in rice

\begin{tabular}{|c|c|c|c|c|c|c|c|c|c|}
\hline \multirow{2}{*}{$\begin{array}{l}\text { Sr. } \\
\text { No. }\end{array}$} & \multirow[t]{2}{*}{ Characters } & \multicolumn{8}{|c|}{ Mean sum of squares } \\
\hline & & $\begin{array}{l}\text { Geno- } \\
\text { types } \\
\text { (G) }\end{array}$ & $\begin{array}{l}\text { Environ- } \\
\text { ments (E) }\end{array}$ & $\begin{array}{l}\text { Genotypes } \\
\text { ×Environ- } \\
\text { ments }(\mathrm{G} \times \mathrm{E})\end{array}$ & $\begin{array}{c}E+ \\
(G \times E)\end{array}$ & $\begin{array}{l}\text { Environ- } \\
\text { ments } \\
\text { (linear) }\end{array}$ & $\begin{array}{c}\text { GxE (lin- } \\
\text { ear) }\end{array}$ & $\begin{array}{l}\text { Pooled } \\
\text { devia- } \\
\text { tion }\end{array}$ & $\begin{array}{l}\text { Pooled } \\
\text { error }\end{array}$ \\
\hline \multicolumn{2}{|c|}{ Degree of freedom } & 53 & 2 & 106 & 108 & 1 & 53 & 54 & 318 \\
\hline 1. & Days to $50 \%$ flowering & $172.00^{* *}$ & $143.26^{* *}$ & 6.18 & $8.67^{* *}$ & $286.51^{* *}$ & $10.51^{* *}$ & 1.80 & 6.89 \\
\hline 2. & Plant height $(\mathrm{cm})$ & $973.89^{* *}$ & 5.01 & 5.17 & 5.16 & 10.02 & 7.36 & 2.92 & 18.43 \\
\hline 3. & Panicle length (cm) & $5.25^{* *}$ & $53.51^{* *}$ & 3.00 & $3.92^{* *}$ & $107.02^{* *}$ & $3.85^{* *}$ & 2.12 & 2.72 \\
\hline 4. & Effective tillers plant ${ }^{-1}$ & $1.30^{* *}$ & $3.88^{* *}$ & 0.74 & 0.80 & $7.76^{* *}$ & 0.72 & 0.74 & 1.59 \\
\hline 5. & Test weight (g) & $23.93^{* *}$ & $182.96^{* *}$ & 1.61 & $4.91^{* *}$ & $365.92^{* *}$ & $3.22^{*}$ & 0.02 & 5.33 \\
\hline 6. & Grain yield plant $^{-1}$ (g) & $5.92^{* *}$ & $39.65^{* *}$ & $2.86^{* *}$ & $3.53^{* *}$ & $79.30^{* *}$ & $3.46^{* *}$ & $2.20^{* *}$ & 1.28 \\
\hline 7. & Grain length (mm) & $2.14^{* *}$ & $0.53^{* *}$ & 0.01 & 0.01 & $1.06^{* *}$ & 0.01 & 0.014 & 0.059 \\
\hline 8. & Grain breadth (mm) & $0.67^{* *}$ & $0.36^{* *}$ & 0.01 & 0.01 & $0.72^{* *}$ & 0.01 & 0.01 & 0.038 \\
\hline 9. & Grain L:B ratio & $1.65^{* *}$ & $1.00^{* *}$ & 0.03 & 0.01 & $2.01^{* *}$ & 0.06 & 0.01 & 0.14 \\
\hline 10. & Hulling (\%) & $3.08^{* *}$ & 0.18 & 0.24 & 0.24 & 0.36 & 0.24 & 0.23 & 1.58 \\
\hline 11. & Milling (\%) & $3.21^{* *}$ & $2.94^{* *}$ & 0.16 & 0.21 & $5.88^{* *}$ & 0.05 & 0.26 & 0.93 \\
\hline 12. & Head rice recovery (\%) & $27.15^{* *}$ & $12.61^{* *}$ & 0.15 & 0.38 & $25.23^{* *}$ & 0.02 & 0.27 & 5.96 \\
\hline
\end{tabular}

$*$, and $* *$ Significant at $(p=0.05)$ and $(p=0.01)$ levels of probability, respectively.

environment interaction for grain yield viz., Belhekar et al. (2004), Munisonnappa et al. (2004), Senapathi and Sarkar (2004), Babu et al. (2005); Bhakta and Das (2008); Das et al.
(2010); Ahmad and Torabi (2011), Waghmode and Mehta (2011), Bose et al. (2012); Patel et al. (2015).

The relative magnitude of linear and non-linear components 
of $\mathrm{G} \times \mathrm{E}$ interaction would decide, whether the performance of a genotype for the character under consideration would be predictable or not? Since, when both linear and nonlinear (pooled deviation) components of $\mathrm{G} \times \mathrm{E}$ interaction are significant, the magnitude of both the components need to be considered and greater magnitude of linear component $[\mathrm{G} \times \mathrm{E}$ $\left.(\mathrm{L})^{*}>\mathrm{G} \times \mathrm{E}(\mathrm{NL})^{*}\right]$ suggests the linear response of genotypes thereby possibility for prediction of performance of genotypes over the environments. Accordingly, three kinds of linear responses $\left(b_{i}\right)$ viz., $b_{i}<1, b_{i}=1$ and $b_{i}>1$ have been considered and interpreted as $b_{i}=1$, average stability and widely adapted to different environments; $b>1$ and significant, above average stability, increasing sensitivity to environmental changes and well adapted to favorable environment and $b_{i}<1$ and significant, below average stability, greater tolerance to environmental changes; thereby genotype would have specific adaptability to poor environment.In consideration to all above requirements and limitations, the stability parameters were worked out and interpreted only for grain yield per plant.

\subsection{Environmental index}

The environmental index computed for the twelve characters studied are presented in Table 2 indicated both the favorable and unfavorable environments for all the component

Table 2: Estimated environmental index for various characters in rice

\begin{tabular}{lcccc}
\hline \multicolumn{1}{c}{ Environment } & \multicolumn{3}{c}{ Environmental index } & \multirow{2}{*}{$\Sigma l^{2}{ }_{j}$} \\
\cline { 2 - 4 } & $E_{1}$ & $E_{2}$ & $E_{3}$ & \\
\hline Days to 50\% flowering & -0.679 & 1.842 & -1.164 & 5.209 \\
Plant height (cm) & 0.030 & 0.285 & -0.316 & 0.182 \\
Panicle length (cm) & -1.076 & 0.214 & 0.862 & 1.946 \\
Effective tillers per plant & -0.170 & -0.136 & 0.306 & 0.141 \\
Test weight (g) & -2.010 & 1.003 & 1.103 & 6.653 \\
Grain yield per plant (g) & -0.771 & 0.910 & -0.138 & 1.442 \\
Grain length (mm) & -0.105 & 0.090 & 0.015 & 0.019 \\
Grain breadth (mm) & 0.087 & -0.073 & 0.014 & 0.013 \\
Grain length : breadth & -0.153 & 0.103 & 0.050 & 0.036 \\
ratio & & & & \\
Hulling (\%) & -0.010 & -0.052 & 0.062 & 0.007 \\
Milling (\%) & 0.210 & -0.247 & 0.037 & 0.107 \\
Head rice recovery (\%) & 0.494 & -0.463 & -0.031 & 0.459 \\
\hline
\end{tabular}

$\mathrm{E}_{1}$ : Kharif 2013; $\mathrm{E}_{2}$ : Kharif 2014; E3: Kharif 2015

characters. The environmental index calculated as the deviation of the mean of all the genotypes at a particular environment from the grand mean of all the genotypes revealed that E2 (Kharif - 2014) recorded a substantial increase in the values of environmental index and proved to be the favorable environment to realize increased grain yield per plant accompanied by increased values in the environmental index for other characters grain length, gain breadth and grain length: breadth ratio.

The environments E3 (Kharif - 2015) are found suitable for days to 50 per cent flowering, plant height, panicle length, effective tillers per plant, test weight and hulling \%. The environment E1 was found to be the suitable for the characters viz., milling and head rice recovery percentage.

\subsection{Phenotypic stability parameters}

The estimates of stability parameters for only grain yield per plant were computed to evaluate relative stability of 54 different genotypes as per Eberhart and Russell (1966). The results are presented in Table 5. The genotypes with higher mean values, regression coefficient value near to unity (bi $=1$ ) and non-significant deviations from linear regression $\left(\mathrm{S}^{2} \mathrm{di}=0\right)$ were considered as stable genotype for that trait and adaptable to varied environmental conditions studied in the present investigation. However, genotypes with a higher mean value and value of regression coefficient more than unity with non-significant deviation from linear regression were considered to be responsive and suitable for favourable environmental conditions. Further, the genotypes with higher mean values and regression coefficient less than unity or negative and non-significant deviations form linear regression were considered to be responsive and suitable for poor environmental conditions. Accordingly, the genotypes were classified as suitable for varied environmental conditions as per Table 3.

The stability parameters of grain yield per plant revealed that 24 genotypes exhibited high mean as compare to population mean. The genotype IR04N 106 (15.42 g) registered the highest grain yield per plant. Out of 54 genotypes studied the genotype TN 1 (6.23 g) exhibited lowest grain yield per plant. The average grain yield per plant over population and environments was $11.00 \pm 0.65 \mathrm{~g}$, hence genotypes with higher grain yield than $11.65 \mathrm{~g}$ were considered as better performing genotypes for grain yield per plant.

Among 54 genotypes, 22 genotypes showed significant deviation from regression showing that their performance could not be predictable over environments and remaining 32 genotypes had non-significant deviation from regression showing the predictability of performance across the environments.

Summarizing the stability parameters it was seen that among all the genotypes which showed unit regression coefficient and non-significant deviation from regression, nine cultivars were identified as most promising as it yielded higher grain yield per plant than population mean coupled with unit regression coefficient and non-significant deviation from regression. The genotypes IR 02A 485, IR 78545-49-2-2, IR 09A 104 showed higher mean value as compared to overall mean and had $\mathrm{bi}>1$ and non-significant deviation from regression, was considered as "variety with above average stability" which indicating that the genotypes were likely to be better adapted to favourable environments and yield reduction is likely in the unfavourable environments (Table 4). 
Table 3: Criteria for classification of genotypes for various characters on the basis of mean performance and stability parameters

\begin{tabular}{|c|c|c|c|c|}
\hline Group & Mean & bi & $S^{2} \mathrm{di}$ & Behavior \\
\hline I & High & Around unity & Around zero & Average response, high stability \\
\hline \multirow[t]{3}{*}{ II } & High & $\begin{array}{l}\text { Significantly deviating from } \\
\text { zero }\end{array}$ & Around zero & \\
\hline & & (i) bi $>1$ & & $\begin{array}{l}\text { Above average response and high stability/better } \\
\text { in good environments }\end{array}$ \\
\hline & & (ii) bi < 1 & & $\begin{array}{l}\text { Below average response and high stability/better } \\
\text { in poor environments }\end{array}$ \\
\hline III & High & $\begin{array}{l}\text { Significantly deviating from } \\
\text { zero }\end{array}$ & $\begin{array}{l}\text { Significantly deviating } \\
\text { from zero }\end{array}$ & Unpredictable behavior \\
\hline IV & High & Around unity & $\begin{array}{l}\text { Significantly deviating } \\
\text { from zero }\end{array}$ & Unpredictable behavior \\
\hline
\end{tabular}

Shanmuganathan and Ibrahim (2005) reported that the high yielding varieties do not necessarily exhibit stability for grain yield over the environments. Bhatka and Das (2008) confirmed that the varieties with low productivity usually exhibit wide

\begin{tabular}{|c|c|c|c|}
\hline \multirow[t]{2}{*}{ Characters } & $\begin{array}{c}\text { Average } \\
\text { stability and } \\
\text { wide/ general } \\
\text { adaptability }\end{array}$ & $\begin{array}{l}\text { Below aver- } \\
\text { age stability } \\
\text { and adapted } \\
\text { to poor envi- } \\
\text { ronment }\end{array}$ & $\begin{array}{l}\text { Above aver- } \\
\text { age stability } \\
\text { and adapted } \\
\text { to better en- } \\
\text { vironment }\end{array}$ \\
\hline & \multicolumn{3}{|c|}{ Genotypes } \\
\hline 1 & 2 & 3 & 4 \\
\hline \multirow[t]{11}{*}{$\begin{array}{l}\text { Grain yield } \\
\text { plant }^{-1}\end{array}$} & $\begin{array}{l}\text { IR } 71700-247- \\
1-1-2\end{array}$ & - & IR 02A 485 \\
\hline & IR 71700-247- & & IR 77734-93- \\
\hline & $1-1-2$ & & 2-3-2 \\
\hline & $\begin{array}{l}\text { IR } 13146-45- \\
2-3\end{array}$ & & IR 09A 104 \\
\hline & IR 04A 395 & & \\
\hline & IR 09A 102 & & \\
\hline & IR 09N 190 & & \\
\hline & IR 10A 110 & & \\
\hline & $\begin{array}{l}\text { IR 78581-12- } \\
3-2-2\end{array}$ & & \\
\hline & GAR 13 & & \\
\hline & Gurjari & & \\
\hline
\end{tabular}

adaptability over a wide range of environments and high yielding genotypes which are brought about by genetic manipulation will necessarily lead to loss of yield stability. The study of Munisonnappa et al. (2004) indicated that high
Table 5: Stability parameter for grain yield per plant in fifty four genotypes in rice

$\mathrm{Sr}$. Genotypes Mean bi $\quad \mathrm{S}^{2}$

No

1. ARC 10550 (ACC12507) $11.10-1.21 \quad 1.65^{*}$

2. ASD 7 (ACC6303) $7.36 \quad 1.17^{* *}++\quad-0.43$

3. Chinsaba (ACC 33016) $7.690 .95^{* *}-0.25$

4. Milyang 46 (cheong- $8.44 \quad-0.01 \quad 0.36$ cheongbyeo)

5. Milyang 54 (gayabyeo) $9.40 \quad 0.56^{*}+\quad-0.36$

6. BG 367-2 $14.81 \quad-0.71 \quad 3.06^{* *}$

7. Milyang $55 \quad 12.35-1.55 \quad 7.6^{* *}$

8. Milyang $63 \quad 8.651 .05^{* *}-0.3$

9. Mudgo (ACC6663) $12.51 \quad 3.06^{*} \quad 2.46^{* *}$

10. Pokkali $8.43 \quad 3.33 \quad 5.49^{* *}$

11. Rathu Heenati $7.84 \quad 0.74 \quad 0.51$ (ACC11730)

$\begin{array}{llll}\text { 12. TN } 1 & 6.23 & 1.31 & 1.41 *\end{array}$

13. Swarnalata (ACC33964) $6.95 \quad 0.9 \quad 0.46$

14. T 12 (ACC 56989) $9.66-1.61 \quad 2.57^{* *}$

15. IR $64 \quad 10.43-0.62 \quad 2.56^{* *}$

16. IR 71700-247-1-1-2 $11.90 \quad 0.99^{* *} \quad-0.34$

17. IR 02A483 $13.93 \quad 1.03 \quad 1.2$

18. РТ В33 $8.31 \quad 2.94^{* *}++\quad-0.16$

19. IR 02A485 $12.411 .38^{* *++}-0.41$

20. IR 77734-93-2-3-2 $12.892 .01^{* *}++\quad-0.4$

21. IR 77186-148-3-4-3 $13.62-0.21 \quad 4.81^{* *}$

22. IR 77542-90-1-1-1-1-5 $10.17 \quad-0.35 \quad 3.51^{* *}$

23. IR 78119-24-1-2-2-2 $9.91 \quad 2.41 \quad 3.51^{* *}$

Continue... 


\begin{tabular}{|c|c|c|c|c|}
\hline $\begin{array}{l}\text { Sr. } \\
\text { No }\end{array}$ & Genotypes & Mean & bi & $\mathrm{S}_{\mathrm{di}}^{2}$ \\
\hline 24. & IR 13146-45-2-3 & 11.87 & $1.53^{*}$ & 0.17 \\
\hline 25. & IR 78545 -49-2-2-2 & 11.61 & $1.31^{* *++}$ & -0.42 \\
\hline 26. & IR 04A 395 & 12.93 & $1.39^{* *}$ & -0.29 \\
\hline 27. & IR 04N 106 & 15.42 & -2.15 & $8.08^{* *}$ \\
\hline 28. & IR $05 N 412$ & 12.55 & 0.19 & 0.18 \\
\hline 29. & IR $06 \mathrm{M} 147$ & 11.56 & $2.49^{*}$ & $1.39 *$ \\
\hline 30 & MUTNS 1 & 9.34 & 0.55 & -0.07 \\
\hline 31. & IR 06N 119 & 12.86 & -0.08 & 0.57 \\
\hline 32. & IR $07 A 166$ & 10.54 & 1.93 & $2.58^{* *}$ \\
\hline 33. & IR 08 N210 & 15.39 & -1.91 & $12.45^{* *}$ \\
\hline 34. & IR 09A 102 & 11.75 & $1.19^{* *}$ & -0.33 \\
\hline 35. & IR 09A 104 & 13.12 & $1.64^{* *++}$ & -0.41 \\
\hline 36. & IR 13540-56-3-2-1 & 7.87 & $0.08^{++}$ & -0.36 \\
\hline 37. & IR 09 A105 & 12.80 & 0.11 & 0.39 \\
\hline 38. & IR 09N 190 & 12.78 & $1.15^{*}$ & -0.13 \\
\hline 39. & IR 09 N379 & 10.37 & 0.96 & $3.18^{* *}$ \\
\hline 40. & IR 09N 496 & 12.22 & $3.3^{*}$ & $3.57^{* *}$ \\
\hline 41. & IR 09N 534 & 10.86 & 3.41 & $4.03^{* *}$ \\
\hline 42. & RP 1486-842-1 & 8.83 & $2.52^{* *+}$ & 0.42 \\
\hline 43. & IR 09N 538 & 10.62 & 6.38 & $16.72^{* *}$ \\
\hline 44. & IR 10A 108 & 10.99 & 2.9 & $3.05^{* *}$ \\
\hline 45. & IR 10A 110 & 12.11 & $1.25^{* *}$ & -0.31 \\
\hline 46 & IR 10A 114 & 12.25 & -0.97 & $2.23^{*}$ \\
\hline 47. & IR 10A 115 & 9.51 & 1.62 & $1.47^{*}$ \\
\hline 48. & $\begin{array}{l}\text { Sinna sivappu (ACC } \\
15444 \text { ) }\end{array}$ & 8.54 & $-0.2^{+}$ & 0.1 \\
\hline 49. & IR 10A 117 & 8.46 & $2.05^{*}$ & 0.79 \\
\hline 50. & IRRI 123 & 7.51 & $0.16^{* *++}$ & -0.43 \\
\hline 51. & IR 78581-12-3-2-2 & 13.77 & $1.64^{* *}$ & -0.03 \\
\hline 52. & GAR 13 & 13.04 & $1.74^{* *}$ & 0.13 \\
\hline 53. & GURJARI & 15.03 & $1.34^{*}$ & -0.03 \\
\hline 54. & GR 11 & 10.91 & $-0.98^{++}$ & 0.21 \\
\hline \multicolumn{2}{|c|}{ Population mean } & \multicolumn{3}{|c|}{11.00} \\
\hline \multicolumn{2}{|c|}{ SEm \pm} & \multicolumn{3}{|c|}{0.65} \\
\hline
\end{tabular}

$*, * *=$ significant at $(p=0.05)$ and $(p=0.01)$ level respectively,

$* *=$ significant at $(p=0.05)$ level when $\mathrm{Ho}: \mathrm{bi}=0 ;++=$ significant at $(p=0.05)$ level when $\mathrm{Ho}: \mathrm{bi}=1$

productivity does not always have stability of production. Hence the findings of the present investigation are in close agreement with the above findings.

\section{Conclusion}

In the study of Borthakur et al. (2005) local cultivars were reported to be stable in four environments created by manipulation of agronomic practices. Differences in stability were found to be both due to differences in linear response of genotypes and deviation from linear response, which is also in conformity with the findings of present investigation.

\section{References}

Ahmad, R., Torabi, M., 2011. Stability analysis of grain yield and its components of rice (Oryza sativa L.) genotypes. Electronic Journal of Plant Breeding 2(4), 484-487.

Ajmera, S., Sudheer Kumar, S., Ravindrababu, V., 2017. Studies on stability analysis for grain yield and its attributes in rice (Oryza sativa L.) genotypes. Int. J. Pure App. Biosci. 5(4), 892-908.

Anonymous (2015). www.fao.org/statistics

Babu, S., Anbumalarmathi, J., Sheeba, A., Yogameenakshi, P. and Rangasamy, P. (2005). Stability performance of salt tolerant rice hybrids. Oryza 42(3), 222-224.

Belhekar, P.S., Jadhav, R.Y., Bhor, T. J., Kamble, S.K., 2004. Genotypexenvironment interaction for yield and yield components in early rice genotypes. J.Maharashtra Agric. Univ., 29(1), 16-19.

Bhakta, N., Das, S.R., 2008. Phenotypic stability for grain yield in rice. Oryza 45(1), 115-119.

Borthakur, D., Dwivedi, J.L., Boruah, T. K., Datta, D., 2005. The stability for grain yield in rice under different agronomic practices. Crop Improv 6(1), 26-29.

Bose, L.K., Nagaraju, M., Singh, O.N., 2012. G×E interaction and stability analysis of lowland rice genotypes. J. of Agri. Sciences 57(1), 1-8.

Das, S., Misra, R.C., Patnaik, M.C., Das, S.R., 2010. G×E interaction, adaptability and yield stability of mid-early rice genotypes. Indian J. Agric. Res., 44(2), 104-111.

Eberhart, S.T., Russell, W.T., 1966. Stability parameters for comparing varieties. Crop Sci., 6, 36-40.

Munisonnappa, S., Vidyachandra, B., Kulkarni, R.S., 2004. Stability analysis in newly developed rice hybrids across dates of sowing during kharif.Karnataka J. of Agric. Sci., 17(4), 696-700.

Patel, B.D., Mehta, A.M., Patel, S.G., Takle, S., Prajapati, S.K., Patel, S.K., 2015. Genotypexenvironment interaction studies in promising early genotype of rice. Electronic Journal of Plant breeding, 6(2), 382-388.

Senapathi, B.K., Sarkar, G., 2004. Adaptability of Aman paddy under Sunderban areas of West Bengal. Indian J. Genet., 64(2), 139-140.

Shanmuganathan, M., Ibrahim, S.M., 2005. Stability analysis for yield and its components in hybrid rice (Oryza sativa L.). Crop Res., 30(1), 40-45.

Sreedhar, S., Dayakar, T., Reddy. Ramesha, M.S., 2011. Genotypexenvironment interaction and stability for yield and its components in hybrid rice cultivars. Internat. J. Plant Breed. and Genet 5(3), 194-208.

Waghmode, B. D. and Mehta, H. D. (2011). G x E interaction and stability analysis in hybrid rice. Crop Improv, 38(1), 6-12. 